\title{
Qualitative Inquiry: A Personal Experience Doing Narrative and Discursive Approach in Relation to Religious Issues
}

\author{
Yusmini Md. Yusoff \\ University of Malaya, yusmini@um.edu.my
}

\begin{abstract}
This article presented an account of the author positioning with the research method and the data texts. It describes the way the author used narrative and discourse analytic inquiry to identify and explore instances of discursive practices in research participants' speaking, as well as the research process and techniques.
\end{abstract}

Keywords: qualitative research, narrative inquiry, discursive practice, ethical stance in research

\section{Introduction}

The primary intention of qualitative inquiry or research is to gather data that provide an authentic insight into research participants' sense of meaning, experiences and understanding. Researchers who adopt qualitative approaches and techniques might consider capturing participants' experiences in their own language as this could offer the opportunity to embrace the meaning of experience first-hand. While the quantitative techniques delivered information in a hard data format, qualitative inquiry worked to give meaning to the participants' world, concerned with the broader concepts of participants' stories, and the contexts that shape and locate those stories ${ }^{1}$. According to Parker ${ }^{2}$ :

People tell stories about particular things that happened to them or about the course of their lives in a certain culturallyspecific way. The order of telling, the puzzling about powerlessness in the face of external forces, the social relations that determine what counts as important for life and the style in which a story is told, are bound together so that it seems as if the individual storyteller is the centre, as observer and actor.

1 David Silverman, Interpreting Qualitative Data: Methods for Analysing Talk, Text, and Interaction, 3rd. ed. (London: Sage Publications, 2006), 20.

2 Ian Parker, Qualitative psychology: Introducing Radical Research (England: Open University Press, 2005), 73-74. 
In this sense, people's experiences and stories are complex. It is a combined composite of who they create themselves as, and who that world makes them and constrains them to $\mathrm{be}^{3}$. This concept stems from postmodernism, and the related notions of a social constructionist epistemology, where its basis rests on language and the making of meaning. The basic idea is that "as we communicate with each other we construct the world in which we live" 4 . Therefore, the making of meaning is a shared and public activity where a word gets meaning because of its usage and place within the language construction that people engage in.

Thus, on these terms, the discussion that follows will be the methodology articulation that has contributed to the author doctoral study and some part of the recent research project conducted in Malaysia ${ }^{5}$. The writing is based on the author's experience doing qualitative inquiry within the framework of narrative and discursive approach. Therefore, in the next section the text will be addressed with the first person 'I' instead of the third person point of view.

\section{Conceptualizing the Selected Research Approach}

Within the narrative and discursive approach, researchers are often involved in the research conversation and the text produced. The relationship is developed in a collaborative way in which both researcher and participant work together to recognize the contextual and interpretative understandings about what is researched $^{6}$. Research interviews within this framework is seen as a way to open a space for dialogic conversation in which "people [the researcher and participant] are talking with each other rather

3 Taylor Stephanie and Littleton Karen. "Biographies in Talk: A NarrativeDiscursive Research Approach," Qualitative Sociology Review, 2 (1), (2006): pp. 22-38.

4 Kenneth Gergen, An Invitation to Social Construction, 2nd. ed. (London: Sage Publications, 2009), 4.

5 UMRG RP029A-16HNE grant with project titled 'Spiritual Abuse Issues Within Religious Deviance: Implication For Da'wah Curriculum Design and Professional Practice'.

6 Gerald Monk, and Diane R. Gehart, "Sociopolitical Activist or Conversational Partner? Distinguishing The Position of the Therapist in Narrative and Collaborative Therapies," Family Process, 42(1), (2003):19-30. 
than to each other" ${ }^{\prime 7}$. From this perspective, research dialogue is positioned as "an interactive process of interpretations of interpretations" $"$, where one interpretation invites another. The purpose of the interpretation process is to help participants and researchers to explore what meanings are produced in the research conversations.

By entering into dialogue with participants, qualitative researchers particularly narrative interviewers who are partnered with their participants may unearth hidden or subordinated ideas ${ }^{9}$ within research conversations. These ideas are important because they may cast doubt on official accounts and established theories. In turn, the findings produced may lead to the development of new theories that resonate more with people's lives ${ }^{10}$.

In the context of my doctoral study and research project, I also used interview conversations as the qualitative material ${ }^{11}$. The development of interview questions was based on an interest in the ways Muslim professionals construct their narratives to make sense of what happens in their working context and professional lives. The intention was to understand the meaning given to the events that happened to these practitioners, and the actions they took in practice with respect to religious and spiritual issues. The aim was to trace how the practitioners' speaking and practice are put together, and how they are connected with the stories of others. In doing so, I perceived participants as authors of their own lives and meaning-makers of the world they reside $\mathrm{in}^{12}$.

During this process, I was aware of my own involvement in the research. Agger explains that the way researchers organise a so-called 'scholarly' investigation and writing, represents certain

7 Harlene Anderson, "Reimagining Family Therapy: Reflections on Minuchin's Invisible Family," Journal of Marital and Family Therapy, 25 (1), (1999): p. 3.

8 Anderson, Harlene. "Myths about "Not-Knowing", Family Process, 44 (4), (2005): p. 499.

9 Heather Fraser, "Doing narrative research." Qualitative Social Work, 3(2), (2004): 179-201.

${ }^{10}$ Fraser, Heather, 184.

11 Andrea Fontana, and James. H Frey,. "The Interview: from Structured Questions to Negotiated Text." In N. K. Denzin and Y. S. Lincoln (Eds.), Handbook of Qualitative Research, 2nd. ed., pp. 645-672 (California: Sage Publications, 2000), 650.

12 Sharlene Nagy Hesse-Biber, Mixed Methods Research: Merging Theory with Practice (New York: Guilford Press, 2010), 64. 
views about what constitutes scholarship and how the scholarship should be conveyed. This scholarship makes possible the exercising of authority and power, and on the basis of that power, researchers might in some way dismiss some participants' points of view in the process of listening to their stories, selecting text, or reporting these stories ${ }^{13}$. Concerns about power served as a guide for me as a researcher to be not so much the privileged author, but perhaps a privileged editor or storyteller of the participants' views.

In the section below, I show the analytic approach that I used to investigate the transcript texts that were produced in the research interviews. Clarify in particular the choices I made about how I selected, wrote and produced the data-representation. I also take up an account of the research process and the ethics of my research relationships with the texts.

\section{Approaches to Qualitative Analysis}

The approaches to analysis that I employed were drawn from a poststructuralist frame, in particular discursive analysis and positioning theory. However, rather than taking these approaches as a set of procedures or formulae to analyze the complexity of the data texts, I used these analytic methods as a guide to understand the constitutive force of discourse in these texts. As Denzin and Lincoln describe ${ }^{14}$, this kind of task is one of the positions that qualitative researchers might take in crafting the analytic process.

The researcher may be seen as a bricoluer, as a maker of quilts, or, as in filmmaking, a person who assembles images into montages. As bricoluer or maker of quilts [the qualitative researcher] uses the aesthetic and material tools of his or her craft, deploying whatever strategies, methods, or empirical materials are at hand. If new tools or techniques have to be invented, or pieced together, then the researcher will do this.

13 Ben Agger, "Critical Theory, Poststructuralism, Postmodernism: Their Sociological Relevance Author(s)," Annual Review of Sociology, 17 (1991): 105-131.

14 Norman K Denzin, and Yvonna S Lincoln, "Intoduction: the Discipline and Practice of Qualitative Research." In Norman K Denzin, and Yvonna S Lincoln (Eds.), The Sage Handbook of Qualitative Research, 3rd. ed., pp. 1-28 (California: Sage Publications, 2005), 4. 
Following what Denzin and Lincoln have suggested, I carried out an approach to analysis of the texts in a way that 'pieces together' possible discursive tools. The analysis of the texts was drawn from discourse analysis theory which studies the ways language produces meanings, but the style of analysis was rather different from some examples of the use of this theory in other studies $^{15}$. My analytic approach was somewhat similar to what Crocket introduced as analyzing "instances of discourse practices" $"$. By this mean, the analytic task concentrated more on the interplay between "discursive practice and discourses-inpractice" 17 , or in Crocket's terms "the discourse practices at work producing us as certain kinds of [practitioners]"18. These practices shape what kind of positions is offered to Muslim practitioners as they engage in discursive practice. In describing this way of going about analysis, Gubrium and Holstein point out ${ }^{19}$ :

At one moment, a researcher might look for discursive practice in order to assess the local availability, distribution, and/or regulation of resources for reality construction. In Wittgensteinian terms, this translates into attending to both language-at-work and language-on-holiday, alternating considerations of how language games, in particular institutional discourses, operate in everyday life and what games are likely to come into play at particular times and places. In Foucauldian terms, it leads to alternating considerations of discourses-in-practice on the one hand and

15 See Fairclough, Norman, Discourse and Social Change (Cambridge: Polity Press, 1992); Potter, Jonathan. "Discourse Analysis and Constructionist Approaches.” In J. T. E. Richardson, ed., Handbook of Qualitative Methods for Psychology and the Social Sciences (Oxford: BPS Blackwell, 1996), pp. 125-140; and Stephanie Taylor, "Locating and Conducting Discourse Analytic Research.” In M. Wetherell, S. Taylor and J. S. Yates (Eds.), Discourse as data: A guide for Analysis (London: Sage Publications, 2001), pp. 5-48,

16 Kathie Crocket, "Narrative Approaches in Counselling Supervision" (PhD. thesis, University of Waikato, Hamilton, New Zealand, 2001), 128.

17 Jaber F. Gubrium, and James A Holstein,. "Analyzing Interpretive Practice." In Norman K. Denzin and Y. S. Lincoln, eds., Handbook of Qualitative Research, 2nd. ed., pp. 487-508 (California: Sage Publications, 2000), 499.

18 Kathie Crocket, "Narrative Approaches in Counselling Supervision", 127.

19 Jaber F. Gubrium, and James A Holstein,. "Analyzing Interpretive Practice." In Norman K. Denzin and Y. S. Lincoln, eds., Handbook of Qualitative Research, 500. 
the locally fine-grained documentation of related discursive practices on the other.

This type of investigation suggests that the participants' linguistic performance about events and phenomena in professional practice is not a neutral description of events or effects but serves specific discursive purposes ${ }^{20}$. Therefore, my work on articulating the practice of discourses in participants' texts was pointed more towards the power of conversational context; what participants said about their practices from moment to moment, working with religious and spiritual issues particularly within Islamic religion ${ }^{21}$. The purpose of investigating participants' moments of speaking was to represent the possible gaps and/or openings in the speaking. These were pieces of information that were sometimes difficult for me to see and interpret, but they led the study to the kind of understanding about how practitioners were shaped and what was possible for them and their clients as they uttered a certain word or phrase or sentence at certain moment. Davies and Harré note ${ }^{22}$ :

Among the products of discursive practices are the very persons who engage in them. An individual emerges through the processes of social interaction, not as a relatively fixed end product but as one who constituted and reconstituted through the various discursive practices in which they participate. Accordingly, who one is, is always an open question with a shifting answer depending upon the positions made available within one's own and other's discursive practices and within those practices, the stories through which we make sense of our own and others' lives.

As the positioning of the participants in this study was shaped by a variety of discursive practices - that is, the practice of institutional policies, and other repertoire such as professionals in Islamic country, cultural and social values or background - the stories participants told and the meanings available to them thus

${ }^{20}$ Rosalind, Gill, "Discourse Analysis: Practical Implementation." In J. T. E. Richardson, ed., Handbook of Qualitative Research Methods for Psychology and the Social Sciences (Oxford: BPS Blackwell, 1996), pp. 141-158.

21 John Shotter, and Arlene M. Katz, "'Living moments' in Dialogical Exchanges," Human Systems, 9, (1999): 81-93.

22 Davies, Bronwyn, and Harré. "Rom Positioning: The Discursive Production of Selves," Journal for the Theory of Social Behaviour, 20(1), (1990): 46. 
varied in terms of how their used language, concepts and discourses that were relevant to their respective profession ${ }^{23}$.

People use words to draw their attention and ours to aspects of their own sayings and doings, to unique details of their lives, that might otherwise pass us both by unnoticed, and particularly, to yet-to-be-created relations between such details.

When I worked with transcript texts, often the unique details were not easily discerned. The texts were not as straightforward as I thought it would be. The texts showed the sequential presentation of participants' stories but their surface did not show the subtle and nuanced meaning also present in each of these stories. In order to understand how a discourse comes to constitute participants, and participants' counselling practices, I lifted an element, a nuance out of the texts to inspect this nuance more closely. This lifting process opened opportunities for me to identify, name and explore the discourses that produce participants' way of working with religious matters. It also helped me to identify the complexities of discursive practices that these discourses produced, and the complex effects of these practices for participants, their clients and their relationships. By exploring 'discursive practice' and discourse-in-practice' at work, I then identified the position calls that come and go when these discourses had called participants into a particular position when meeting with religion and spirituality ${ }^{24}$. The positions that participants occupied in the moment, therefore, led me to explore the complexities of shifting relations of power in therapeutic encounter. This power relation exists between participants and client. It also exists within participants' work setting.

\section{Engaging with the Research Text}

For this section, I will focus on how the analysis of interview texts was carried out. I transcribed all interview transcripts into Malay language, since the interview conversations were performed in

23 John Shotter, and Arlene M. Katz, “'Living Moments' in Dialogical Exchanges." 82.

24 Wendy Drewery, "Why We Should Watch What We Say: Position Calls, Everyday Speech and the Production of Relational Subjectivity," Theory \& Psychology, 15(3), (2005): 305-324. 
Malay. The challenge was to remain close to the original words and participants' context while transcribing. This includes not having missed or lost participants' emotional aspects, the individual situation, and the overall cultural context of the participants. These transcripts then were sent to participants for revision, in order to maximise the accuracy of these transcripts, and to represent participants' stories in their own terms.

During the process of analysing transcripts, one of the challenges was to break up long chunks of talk into specific stories $^{25}$. One way of doing this was I initially listed the narratives and discourses that emerged from our research conversation. I organised these narratives and discourses into themes that reflected my questions and the interest of the study. I looked for consistency in participants' language use, stories and ideas. I also noted any information that seems to contradict with these ideas. The aim was to see whether there were relationships among the discursive themes, and I identified the connection between participants' subjectivity and positioning when meeting with religious values. In this phase, I wrote down some of the specificities in each transcript. Then, I named stories so that I could extend my recall of the sets of ideas these stories contained. For example, I called one participant's story, 'Saya Pesuruh Allah' (I am God's worker) and I displayed the sentences taken from the middle of the quote in the following way:

Participant X: Saya berpegang kepada konsep bekerja untuk Allah. Saya bekerja untuk membawa manusia kembali kepada fitrah.

I hold the concept of working for God, I work to bring mankind [sic] to their nature.

I also named stories from the actual phrases that participants used. For instance, while analysing participants' views about their training programmes in relation with religious and spiritual issues, I called one story 'Latihan yang saya terima seperti menarik saya dari menjadi diri sendiri' (The training pulls me away from who I am). This caption was taken from the participant's utterance:

Participant Y: Macam mana saya nak jelaskan hal ni...ia seperti belajar Matematik atau Bahasa, yang mana saya

25 Heather Fraser, "Doing narrative research," Qualitative Social Work, 3(2), (2004): 179-201. 
tidak boleh masukkan unsur akidah ke dalamnya sebab ia [Matematik atau Bahasa] tidak diasaskan atas akidah atau aspek kerohanian. Latihan ni bersifat sekular. Ia menarik saya dari menjadi diri sendiri [sebagai orang yang berpegang kepada agama].

How can I explain this...it is like studying maths or language, which I could not put my faith in it because it is not built on the faith or spiritual aspect. It [the training] is purely secular. It pulls me away from who I am [as a religious person].

Throughout the process, I was mindful of my position as a researcher in relationship to the research texts; about how I might interpret or misinterpret, manipulate, or produce meanings about the texts. I was aware of my own personal positions that might constitute the interpretative work that I did, and the processes of understanding participants' stories ${ }^{26}$. On working with interpretative views of data, Geertz reminds $\mathrm{us}^{27}$ :

What we call our data are really our own constructions of other people's constructions of what they and their compatriots are up to.

Therefore, when I was selecting the research texts and analyzing findings, I was careful of the potential risks involved in interpreting someone's story, and about going public with their stories in order to be in relationship with my readers. I questioned the ownership of these narratives. I asked: who wields the final presentation and interpretation?; who owns the research participants' narratives? Chase in addressing the matter of ownership points out ${ }^{28}$ :

Who should control the interpretive process in any particular case depends in large part on the aim or purpose of the research and thus what kind of material needs to be collected and what kind of interpretation best suits that material. As long as decisions about these are made by the researcher

${ }^{26}$ Catherine Kohler Riessman, Narrative Analysis (California: Sage Publications, 1993), 22.

27 Clifford Geertz, The Interpretation of Cultures (New York: Basic Books, 1973), 9.

28 Susan E. Chase, "Personal Vulnerability and Interpretative Authority in Narrative Research." In R. Josselson (Ed.), The Narrative Study of Lives (vol. 4): Ethics and Process in the Narrative Study of Lives, pp. 45-59 (California: Sage Publications, 1996), 51-52. 
[which is in line with the research aims]... I believe that claiming and acknowledging one's interpretative authority is imperative.

Hence, given that each participant spoke about their own particular practice, my position and responsibility as researcher required me to relate the meaning of these stories to the larger theoretical considerations. This way, the interpretation of discourses employed by participants can be described in a more contextualised manner, concentrating on "relations among particulars rather than abstract generalities" 29 , so that one's intention can be addressed, and neither be misinterpreted nor overinterpreted. I see that this responsibility as incumbent on me as researcher.

The hardest part in writing and analysing transcript texts was to learn to read them in a way that would keep me from fitting participants' stories into what I think I know, that is from accessing only knowledge that told me what to read and how to interpret what these participants are saying. This was evident when there was a moment where I came to the point of impossibility. Impossibility is the point where there was a contradiction between what participants told me, a discrepancy that I could not make sense of, or when participants spoke about matters that were dissonance with my own beliefs and values, - and thus contested these values. For Parker, this feeling of impossibility is not necessarily an error nor had I failed to gather enough information. He argues ${ }^{30}$ :

Psychology should not a search for ways to fit things together as if that is the way of truth. Instead it may be that differences of viewpoint between the different participants, (or between the participants and ourselves) are a function of such radically different lived realities and conflicts of political perspective that it would actually be a mistake to try and smooth over those differences using one overall covering account.

${ }^{29}$ William E. Smythe, and Maureen J. Murray, "Owning the Story: Ethical Considerations in Narrative Research." In M. Nind K. Sheehy, J. Rix and K. Simmons (Eds.), Ethics and Research in Inclusive Education: Values into practice, pp. 176-191, (Oxford: Routledge, 2005), 183.

30 Ian Parker, Qualitative Psychology: Introducing Radical Research (England: Open University Press, 2005), 15-16. 
In finding ways to work with such situations, I tried to be very careful to interpret what participants meant by a certain word, or to make sure that I attended to what was missing. For example, I considered talk that appeared to be unnoticed by participants, or unable to be spoken in their speaking ${ }^{31}$. I tried to show what these practitioners tend to accomplish by telling their stories in a particular fashion. Within the process, I undermined the usual assumption: that people say what they mean, and only mean what they say. I tried to show that everything that has been said perhaps has other meanings, or purposes that are not immediately visible. This approach, alongside the understanding of poststructuralist theoretical context about discourses at work, has helped me to maintain a respectful relationship with the text as I had had with my participants during the interview conversation.

However, there was a concern that in doing so I would not describe participants' stories fully in their personal uniqueness and individuality. Josselson puts it succinctly about her position on writing other people's lives, she says ${ }^{32}$ :

I do not worry much about betraying confidentiality. I disguise in such a way that I am certain that no one else could recognise the people whom I write...But I worry intensely about how people will feel about what I write about them. I worry about the intrusiveness of the experience of being "writ down", fixed in print, formulated, summed up, encapsulated in language, reduced in some way to what the words contain. Language can never contain a whole person.

Like Josselson, I also acknowledge this dilemma in my own writing. My participants were not actively involved in the process of analysis. However, I took a few steps for ensuring the transparency of this research, and not avoiding or neutralizing my own bias and reasoning. Following the ethics in doing qualitative research, I first sent participants the final transcripts for them to

31 Kathryn Anderson, and Dana C. Jack "Listening to listen: Interview Techniques and Analysis." In S. B. Gluck and D. Patai (Eds.), Women's words: The Feminist Practice of Oral History, pp. 11-26 (New York: Routledge, 1991).

32 Josselson, Ruthellen, “On writing other people's lives: Self-Analytic Reflections of a Narrative Researcher." In R. Josselson (Ed.), The Narrative Study of Lives (vol. 4): Ethics and Process in the Narrative Study of Lives, pp. 60-71 (California: Sage Publications, 1996), 62. 
verify and give feedback, in which they could comment, and edit the transcripts for accuracy. Second, I maintained constant discussions with my academic peers/supervisors in relation with these findings. These steps allowed me the space to be cautious of the possibilities of misleading and/or exploiting what participants meant in their texts, and kept me from writing down something that could be interpreted as criticising them. In this position, I wanted to acknowledge and honour what participants had offered and contributed to the study, and I did not want my authorship to drown out their voices. However, at the same time I also wanted to remain close to the political side of the research, when I positioned myself in relation to those who may read my research reports and those who may experience the world in ways that are different from my own views or participants' views. I wanted to take some responsibility for what I have analysed and produced. In this sense, I offer different possible interpretations, and I hope the implications of these interpretations will contribute to enhancing participants' practice in working with religious and spiritual issues. I considered this way of writing and reporting is within the interest of what Parker writes as "fidelity to commitments made during a research event is the space for ethics"33, something that feminist research has always recognised ${ }^{34}$.

\section{Conclusion}

Qualitative inquiry attends to the lived experiences of those who participate in a given research project. The discussion in this article seeks to contribute to the material available about how narrative and discursive approach might be done by bringing my own experience into the text. Although I have brought forth the possible phases of the work, this is by no means a definitive approach. It is only a rough guide that I offer for other interested qualitative researchers to generate their own ideas about

33 Ian Parker, Qualitative Psychology: Introducing Radical Research, 14.

${ }^{34}$ See Judith Butler, Gender Trouble, Feminist Theory, and Psychoanalytic Discourse. In L. M. Alcoff and E. Mendieta, eds., Identities: Race, Class, Gender and Nationality (Massachusetts: Blackwell Publishing, 2003), pp. 201226; Rachel T. Hare-Mustin, and Jeanne Marecek, Making a Difference: Psychology and the Construction of Gender (New Haven: Yale University Press, 1990); and, Bell Hooks, Feminist Theory: From margin to Center, 2nd. ed. (London: Pluto Press, 2000). 
qualitative works. By saying that, it is noteworthy to keep in mind that for researches in religious and spiritual paradigm specifically in Theology and Ușūl al-Dīn studies, including in Manțīq, Qawā'id Tafsìr and Usūul al-Fiqh (to name a few) there are other principles and methods that are possible to be used in relation to language and meanings. Therefore, a careful consideration to analyze meaning embedded in Islamic religious discourse should be emphasized because language and meaning which is constructed in Islamic discourse might differ from the actual meaning made by the Prophet Muhammed and other Islamic ways of interpretations.

\section{Acknowledgement}

I acknowledged the many contributions of my supervisors, Associate Professor Dr. Kathie Crocket and Dr. Elmarie Kotzé at the University of Waikato, New Zealand, particularly for introducing me to the qualitative research which enabled me to see the world through 'new lenses'. I equally thanked University of Malaya for the support offered through my doctoral scholarship (2006-2010), and UMRG grant (UMRG RP029A-16HNE) which encouraged my continuing involvement in researching and writing.

\section{References}

Anderson, Harlene. "Myths about "Not-Knowing", Family Process, 44 (4), (2005): p. 499.

Anderson, Harlene. "Reimagining Family Therapy: Reflections on Minuchin's Invisible Family." Journal of Marital and Family Therapy, 25(1), (1999): p. 3.

Anderson, Kathryn and C. Jack, Dana. "Listening to listen: Interview Techniques and Analysis." In S. B. Gluck and D. Patai (Eds.), Women's words: The Feminist Practice of Oral History, pp. 11-26. New York: Routledge, 1991.

Ben Agger, "Critical Theory, Poststructuralism, Postmodernism: Their Sociological Relevance Author(s)." Annual Review of Sociology, 17 (1991): 105-131.

Bronwyn, Davies, and Harré. "Rom Positioning: The Discursive Production of Selves." Journal for the Theory of Social Behaviour, 20(1), (1990): 46. 
Butler, Judith. Gender Trouble, Feminist Theory, and Psychoanalytic Discourse. In L. M. Alcoff and E. Mendieta (Eds.), Identities: Race, Class, Gender and Nationality. Massachusetts: Blackwell Publishing, 2003.

Chase, Susan E., "Personal Vulnerability and Interpretative Authority in Narrative Research." In R. Josselson (Ed.), The Narrative Study of Lives (vol. 4): Ethics and process in the narrative study of lives, pp. 45-59. California: Sage Publications, 1996.

Crocket, Kathie. "Narrative Approaches in Counselling Supervision". Phd thesis, University of Waikato, Hamilton, New Zealand, 2001.

E. Smythe, William, and J. Murray, Maureen. "Owning the Story: Ethical Considerations in Narrative Research." In M. Nind K. Sheehy, J. Rix and K. Simmons (Eds.), Ethics and Research in Inclusive Education: Values into practice, pp. 176-191. Oxford: Routledge, 2005.

F. Gubrium, Jaber, and A Holstein,. James. "Analyzing Interpretive Practice." In Norman K. Denzin and Y. S. Lincoln (Eds.), Handbook of Qualitative Research, 2nd. ed., pp. 487508. California: Sage Publications, 2000.

Fontana, Andrea and H Frey, James. "The Interview: from Structured Questions to Negotiated Text." In N. K. Denzin and Y. S. Lincoln (Eds.), Handbook of Qualitative Research, 2nd. ed., pp. 645-672 (California: Sage Publications, 2000), 650.

Fraser, Heather. "Doing Narrative Research." Qualitative Social Work, 3(2), (2004): 179-201.

Fraser, Heather. "Doing Narrative Research." Qualitative Social Work, 3(2), (2004): 179-201.

Geertz, Clifford. The Interpretation of Cultures. New York: Basic Books, 1973.

Gergen, Kenneth. An Invitation to Social Construction. 2nd. ed.. London: Sage Publications, 2009.

Gill, Rosalind. "Discourse Analysis: Practical Implementation." In J. T. E. Richardson (Ed.), Handbook of Qualitative Research Methods for Psychology and the Social Sciences. Oxford: BPS Blackwell, 1996. 
Hare-Mustin, Rachel T. and Marecek, Jeanne. Making a Difference: Psychology and the Construction of Gender. New Haven: Yale University Press, 1990.

Hesse-Biber, Sharlene Nagy. Mixed Methods Research: Merging Theory With Practice. New York: Guilford Press, 2010.

Hooks, Bell. Feminist Theory: From margin to Center. 2nd. ed. London: Pluto Press, 2000.

Josselson, Ruthellen, "On Writing Other People's Lives: SelfAnalytic Reflections of a Narrative Researcher." In R. Josselson (Ed.), The Narrative Study of Lives (vol. 4): Ethics and Process in the Narrative Study of Lives, pp. 60-71. California: Sage Publications, 1996.

K Denzin, Norman, and S Lincoln, Yvonna. "Intoduction: the Discipline and Practice of Qualitative Research." In K Denzin, Norman and S Lincoln, Yvonna (Eds.), The Sage Handbook of Qualitative Research, 3rd. ed., pp. 1-28. California: Sage Publications, 2005.

Monk, Gerald, and R. Gehart, Diane. "Sociopolitical Activist or Conversational Partner? Distinguishing the Position of the Therapist in Narrative and Collaborative Therapies." Family Process, 42(1), (2003):19-30.

Norman, Fairclough. Discourse and Social Change. Cambridge: Polity Press, 1992.

Parker, Ian. Qualitative Psychology: Introducing Radical Research (England: Open University Press, 2005.

Parker, Ian. Qualitative Psychology: Introducing Radical Research. England: Open University Press, 2005.

Potter, Jonathan. "Discourse Analysis and Constructionist Approaches." In J. T. E. Richardson (Ed.), Handbook of Qualitative Methods for Psychology and the Social Sciences. Oxford: BPS Blackwell, 1996.

Riessman, Catherine Kohler. Narrative Analysis. California: Sage Publications, 1993.

Shotter, John, and M. Katz, Arlene. "'Living moments' in Dialogical Exchanges.” Human Systems, 9, (1999): 81-93.

Silverman, David. Interpreting Qualitative Data: Methods for Analysing Talk, Text, and Interaction. 3rd. ed. London: Sage Publications, 2006. 
Stephanie, Taylor, and Karen. Littleton. "Biographies in Talk: A Narrative-Discursive Research Approach." Qualitative Sociology Review, 2 (1), (2006): pp. 22-38.

Taylor, Stephanie. "Locating and Conducting Discourse Analytic Research." In M. Wetherell, S. Taylor and J. S. Yates (Eds.), Discourse as data: A guide for Analysis. London: Sage Publications, 2001.

UMRG RP029A-16HNE grant with project titled 'Spiritual Abuse Issues Within Religious Deviance: Implication for Da'wah Curriculum Design and Professional Practice'.

Wendy. Drewery. "Why We Should Watch What We Say: Position Calls, Everyday Speech and the Production of Relational Subjectivity." Theory \& Psychology, 15(3), (2005): 305-324. 